\title{
HERITAGE SIGNIFICANCE OF LATE 19TH AND EARLY 20TH CENTURY BUILDINGS IN THE BUGANDA KINGDOM, UGANDA
}

\author{
GILBERT KAFUUMA, ESTHER MUHWEZI \& MARK R. O. OLWENY \\ Faculty of the Built Environment, Uganda Martyrs University, Uganda
}

\begin{abstract}
The paper sets out to investigate the heritage significance of four late 19th and early 20th century buildings in Buganda capital of Mengo. The buildings, Keweerimidde House (1890s), Basiima House (1902), Chwa Building (1904), and Muteesa I Dormitory (1904), were built during an extraordinarily tumultuous period in the history of the Kingdom which no doubt had an impact on the buildings that were constructed, and their subsequent use over the years. The exploration is undertaken through an approach that combines two exploratory techniques: values and narratives. These are used to investigate the many tales that surround these buildings, while reflecting on the socio-political developments of the period, which also influenced their commissioning and construction. This led to a better understanding of the embedded relationship between the specific buildings and the stories that are often neglected in discourse of heritage in the context of Uganda. A key part of the study was the documentation of the four buildings, which revealed a further dimension of heritage studies, such as cultural changes in Buganda during the period under question. Through this evaluation, the paper seeks to contribute to the understanding and appreciation of architecture of this period, while at the same time building a documented inventory of these buildings.
\end{abstract}

Keywords: significance, historic buildings, heritage conservation, culture.

\section{INTRODUCTION}

According to [1], buildings are an important part of tangible heritage, and represent an unrepeatable stock of the history of a society, serving as educational centres and cognitive environments for forming today's new generation of beliefs, self-confidence, and identity. Buildings reflect people's needs and are the most complete and accurate witnesses to the material and social conditions of an age [2]. As such, it is necessary in the construction of a narrative of a society to look not only at the buildings, but also the ideas and process of their construction, as well as the social and political conditions under which the buildings were manifested, acknowledging that buildings can and do have multiple meanings, that can be unpacked through an evaluation of their histories, [3] states. This study explores narratives associated with key buildings constructed in Buganda Kingdom during the late nineteenth and early twentieth centuries. While much attention and effort has been given to the UNESCO World Heritage listed, Kasubi Tombs, neglect of buildings that showcase cultural change leave out significant elements of the narrative. The buildings in question Keweerimidde House (1890s), Basiima House (1902), Chwa Building (1904) and Muteesa I Dormitory (1904) - were commissioned and constructed during a particular tumultuous period in the history of Buganda. During this period, religious factions were vying for cultural and political patronage from the Kabaka (King of Buganda). At the same time, there was cultural intrusion, largely arriving as part of the colonial project, in this case England, presented as a modernisation project. The paper provides an overview of the stories surrounding the selected buildings seeking to situate them within the socio-cultural and political discourse of the time. The goal is to explore the heritage significance of these buildings, geared to raising awareness of these buildings as part of the often neglected built heritage of Uganda. 


\section{APPROACHES TO HERITAGE CONSERVATION}

Heritage conservation as a discipline is "devoted to preservation of cultural property for the future" [4]. Various approaches to heritage conservation have been developed since the birth of the discipline, and include: values-based, narrative-based, and living heritage approaches. The values-based approach focuses on protecting the significance of a property as determined by the values of a society ascribing to it [5], while the narrative-based approach focuses on preservation of a property as determined by the stories associated with the property [6]. The living heritage approach focuses on maintaining continuity of the original function of the property and its connection to the community while considering the evolving tangible (material) and intangible (practices and traditions) aspects of a property in response to the changing circumstances [7]. All three approaches are still applicable today, although used in different contexts, depending on the specific circumstances. For the current study, the living heritage approach is the most applicable as it: (i) attempts to balance the use of the heritage property (by the community in accordance with its connection to the property) and the protection of the property (by conservation professionals) [7]; (ii) embraces change over time, thus asserting the relevance of the property to contemporary society [8]; and (iii) examines and highlights the narrative and values that underline the significance of a heritage property [9]. Following the living heritage approach, the paper explores the heritage value of the buildings in question and assesses the condition of their tangible (physical aspects) and intangible (practices, traditions and events) expressions. In order to fully appreciate the buildings in question, it is necessary to provide a background to the history and context of Buganda at the time of their construction.

\section{BUILDINGS OF FOREIGN INFLUENCE WITHIN BUGANDA}

Buganda is one of the autonomous kingdoms of the interlacustrine region of East Africa, to the north and west of Lake Victoria. Ruled by a king (Kabaka), the kingdom was, by late 19th century, the most powerful kingdom in the region, at the centre of which was its capital, the Kibuga, where the Kabaka and chiefs resided. Intriguingly, the capital was periodically relocated, generally after the coronation of a new Kabaka as a symbol of a new beginning, but in some cases during the reign of a Kabaka for security or reasons of hygiene [10]. With the arrival of foreign influence during the late 19th century, this all came to an end, with the Kibuga making its final move to Mengo in 1884 under the reign of Kabaka Mwanga. As the protectorate government settled into the adjacent headquarters of Kampala, the opportunity of relocation was extinguished, more so as hilltops desired by the Kabaka for the location of their capitals were now in the hands of different groups: the protectorate government and different religious institutions.

A key mission of the Christian missionaries was their evangelism, for which they needed to ensure converts could read the bible. It was therefore imperative that the Baganda (people from Buganda) be taught how to read and write. With more and more Baganda embracing Christianity, they also began to emulate the missionaries' lifestyle; in the way they dressed, the food they ate, the festivities they engaged in, and in their architectural preferences, more so among the ruling class, the wealthy chiefs, who were keen to express and assert their engagement with modernity. By the 1890s, many of the leading chiefs had started building houses in European style [11], exemplified by Basiima House by (Sir) Apollo Kaggwa, the Buganda Katikiro (Prime Minister) at the time, and Keweerimidde House by Ham Mukasa, secretary to Apollo Kaggwa. These residential buildings certainly evoked a sense of awe among their fellow Baganda. At the same time, school buildings like, Chwa Building and Muteesa I Dormitory at Mengo Primary School at Namirembe, Kampala, were commissioned and constructed by the missionaries of the Church Missionary Society (CMS). This was to 
provide learning spaces for students but also acted as platforms where the merits of Christian values were espoused. Delving into the history of these four buildings would provide an idea of how they constitute a valuable part of the built heritage of Buganda.

\section{THE BUILDINGS}

\subsection{Chwa Building and Muteesa I Dormitory}

Chwa Building (Fig. 1) and Muteesa I Dormitory (Fig. 2) were the first "permanent" school buildings built for Mengo Primary School in 1904, lauded as the first formal school in Uganda. The CMS had established the school at Mengo to teach the sons and daughters of the Baganda aristocracy (members of the royal family, and sons of chiefs) how to read and write to ensure they could read the bible and related religious literature [12], [13]. Initial instruction was given by Miss Chadwick, who, in 1895, set up an informal school in her home to teach students how to read and write [14]. A few years later in 1898, a formal school for boys was established by Mr. Hattersley, Mengo Boys' School, where he offered bible classes and taught boys how to read and write [14]. Mengo Boys' School grew into the present-day Mengo Primary School.

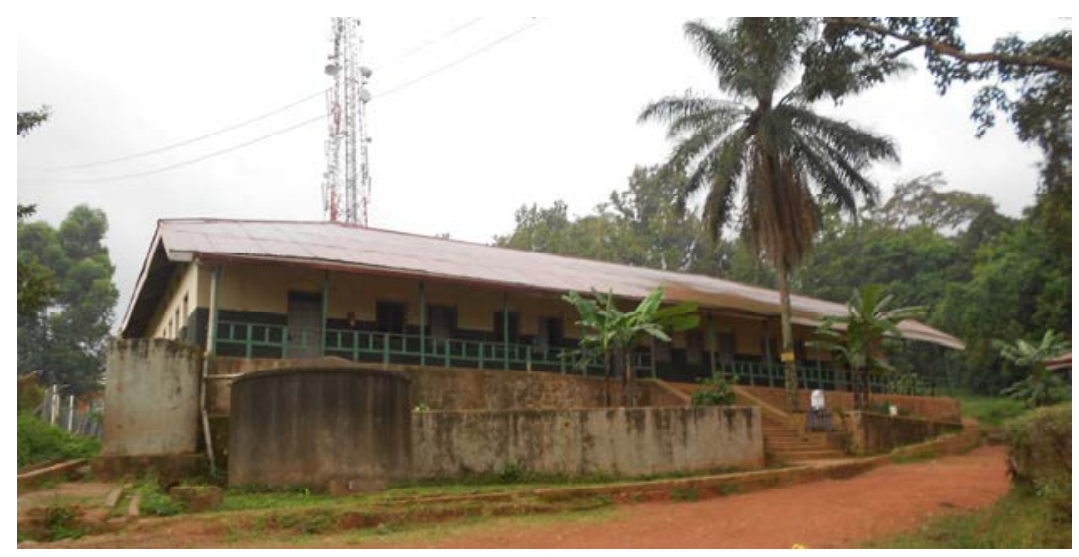

Figure 1: Chwa Building. (Source: Author, 2018.)

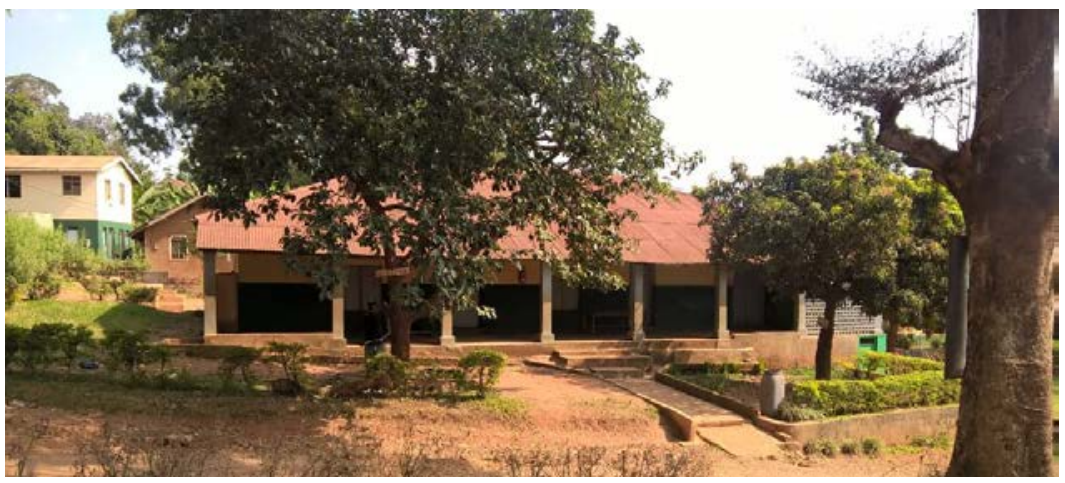

Figure 2: Muteesa I Dormitory. (Source: Author, 2018.) 
The two buildings in question were commissioned and constructed by the CMS, borrowing heavily from bungalow typology that had been established in the British Indian colony [12]. Both buildings were built using local materials - sun-dried mud and straw brick for the walls, palm poles for the roof truss, and thatch for the roof - required a substantial Bakopi (peasants) labour force [15], as this mode of construction was largely unknown, and required significant attention.

\subsection{Basiima House}

Basiima House (Fig. 3) was the official residence of (Sir) Apollo Kaggwa, the Katikiro of Buganda from 1888 to 1925 . He was also one of the three Regents to the child Kabaka Daudi Chwa II, (between 1897 and 1914). The Basiima House was constructed between 1902 and 1903, and was a result of the fusion of ideas gathered by Kaggwa during his trip to England for the coronation of King Edward VII in 1902 [16]. During his visit, Kaggwa visited numerous stately homes in London, many catching his fancy, and leading him to muse that it would be possible for his fellow countrymen to reach the same level of development and innovation if they were provided with the knowledge and skills to do so. On his return to Buganda, Kaggwa built Basiima House to display the ideas he had acquired from his visit. The house was built using fired clay brick, and incorporated several ideas derived from England, including: chimneys, internal bathrooms, and electric bells [17].

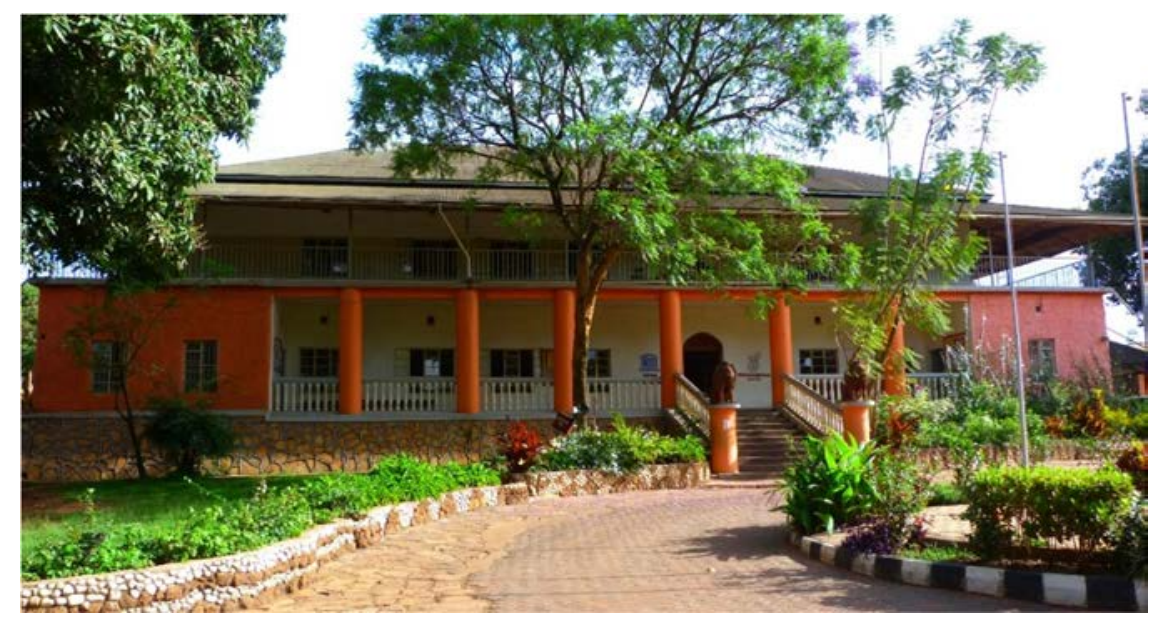

Figure 3: Basiima House in 2017. (Source: Author, 2017.)

\subsection{Keweerimidde House}

Keweerimidde House (Fig. 4) was the official residence for Ham Mukasa, the Private Secretary to Apollo Kaggwa. The house, also in Mengo, was originally constructed in the late 1890s using sun-dried mud and straw brick for the walls, palm poles for the roof truss, and thatch for the roof. As a Private Secretary to Apollo Kaggwa, Mukasa had travelled to England in 1902 to attend the coronation of King Edward VII. He too was struck by the homes he had visited during his visit to England, and on his return to Buganda, set about remodelling Keweerimidde House to incorporate some of the ideas - internal bathrooms and electric bells - he had seen. 


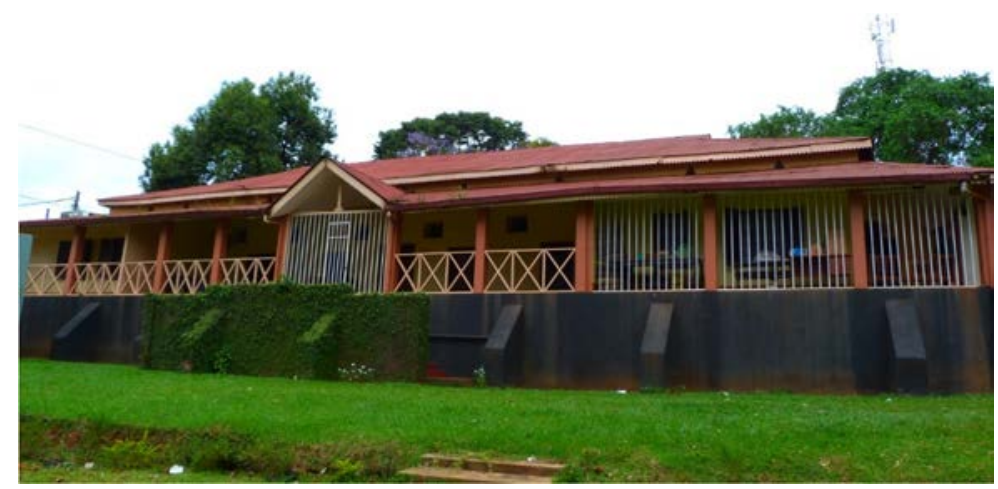

Figure 4: Keweerimidde House in 2017. (Source: Author, 2017.)

\section{SIGNIFICANCE OF THE BUILDINGS}

Looking at all four buildings, they could all be characterised by what [18] describe as a pragmatic synthesis of western imports and local resources, the most prominent example being the "bungalow" which formed the basis for domestic and school architecture of the early colonial era in Uganda. The houses were characterised by large verandas on all four sides, but built with indigenous building technologies - in this case, sun-dried mud and straw brick, with compacted earth or timber floors, ceilings made with timber or papyrus mats, window openings with timber shutters and roof covered with thatch [18]. The hybrid nature of these buildings, with tier overtly western form, and spatial layout were the first expression of Western modernity in building, and demonstrated a cultural and technological transformation as the English tried to adapt their buildings to the local materials and conditions, while the Baganda aristocrats looked to emulate what had been seen overseas. The architecture of these buildings thus provides a glimpse of the first expression of Western modernity in Buganda, which influenced many subsequent buildings.

The significance of these buildings to the Buganda Kingdom was seen in how they were incorporated into the day-to-day activities of the Kibuga, more so for the Chwa Building and the Muteesa I Dormitory, which acquired the names of Kabaka Muteesa I and Chwa II. Kabaka Daudi Chwa II formally opened the building, planting a Muvule tree (Chlorophora exessia) as part of the ceremony, a tree that holds particular significance in the kingdom. The link between the kingdom and CMS is embedded in the naming of these two buildings, acknowledging Kabaka Muteesa I, grandfather of Daudi Chwa, who invited the CMS to Buganda [19]. Kabaka Daudi Chwa II was the reigning Kabaka when the school buildings were constructed, and Uganda was declared a British Protectorate. Linked to the royal institution Apollo Kaggwa and Ham Mukasa made a significant contribution not only to the Buganda Kingdom, but also to the social development of the region. Mukasa was an advocate to formal education for all Baganda, and was key in the founding of numerous schools, including King's College Budo, and Gayaza High School. For this reason, he is often referred to as a "scholar who never went to school".

\section{CONCLUSION}

The paper has presented part of the narrative, associated with some early influential buildings in Buganda, showcasing some of the social and political developments that led to their existence during the late 19 th and early 20 th centuries. The value of such investigations are such that the true value of these and other buildings of this period of immense interaction 
between different cultures can be brought to the fore, contributing to our appreciation of the transformation of architecture at the time. An understanding and appreciation of these buildings, and the socio-cultural and political conditions under which the buildings were manifested provides a clearer picture of the value of these works of architecture as key markers in the development of architecture in the region, and its many and diverse influences.

\section{ACKNOWLEDGEMENT}

We would like to express our special thanks of gratitude to our supervisor Dr Mark R.O. Olweny for his patience, guidance, and giving us the opportunity to take on this research.

\section{REFERENCES}

[1] Barvika, S., Capturing the value of architectural heritage. Magazine of the International Association of Assessing Officers, 14(5), pp. 3-14, 2016.

[2] UNESCO, Preserving and Restoring Monuments and Historic Buildings, United Nations Educational Scientific and Cultural Organisation: Paris, 1972.

[3] Whyte, W., How do buildings mean? Some issues of interpretation in the history of architecture. History and Theory, 45(2), pp. 153-177, 2006.

[4] Munos-Vinas, S., Contemporary Theory of Conservation, Elsevier ButterworthHeinemann: Oxford, 2005.

[5] Fredheim, L.H. \& Khalaf, M., The significance of values: Heritage value typologies re-examined. International Journal of Heritage Studies, 22(6), pp. 466-481, 2016.

[6] Walter, N., From values to narrative: A new foundation for the conservation of historic buildings. International Journal of Heritage Studies, 20(6), pp. 634-650, 2014.

[7] Poulios, I., Discussing strategy in heritage conservation: Living heritage approach as an example of strategic innovation. Journal Cultural Heritage Management and Sustainable Development, 4(1), pp. 16-34, 2014.

[8] Wijesuriya, G., The past is in the present: Perspectives in caring for Buddhist heritage sites in Sri Lanka. Conservation of living religious heritage. Papers from the ICCROM 2003 Forum on Living Religious Heritage: Conserving the Sacred, pp. 30-43, 2005.

[9] ICCROM, People-Centred Approaches to the Conservation of Cultural Heritage: Living Heritage, International Centre for the Study of the Preservation and Restoration of Cultural Property: Rome, 2015.

[10] Olweny, M., Politics, religion, and architecture in Uganda. Proceedings from the XXIVth International Conference of the Society of Architectural Historians, Australia and New Zealand, pp. 1-16, 2007.

[11] Hattersley, C.W., Uganda by Pen and Camera, The Union Press: Philadelphia, 1907.

[12] Uganda Church Review, Education, April(2), pp. 47-53, 1926.

[13] McGregor, G.P., King's College Budo. The First Sixty Years, Oxford University Press: London, 1967.

[14] Wandira, A., Early Missionary Education in Uganda, Makerere University Press: Kampala, 1972.

[15] Scalon, D., Education in Uganda, US Department of Health, Education and Welfare, Office of Education: Washington, DC, 1964.

[16] Johnston, H., The Uganda Protectorate, Vol. 2, Hutchinson: London, 1904.

[17] Miller, E. Uganda's Katikiro in England by Ham Mukasa, Hutchinson: London, 1904.

[18] Tzonis, A., Lefaivre, L. \& Stagno, B., Tropic Architecture: Critical Regionalism in the Age of Globalisation, Wiley Academy: Chichester, 2001.

[19] Low, D.A., The Mind of Buganda: Documents of the Modern History of and African Kingdom, University of California Press: California, 1971. 